\title{
Growth, yield and oil content of sesame (Sesamum indicum L.) as influenced by sulphur levels under infertile soil
}

\author{
Darika Bunphan ${ }^{1 *}$, Ruchuon Wanna ${ }^{1}$, Wanwipa Pinta ${ }^{2}$, Goitseone Malambane ${ }^{3}$ \\ ${ }^{1}$ Department of Agricultural Technology, Faculty of Technology Mahasarakham University, Kantarawichai District, \\ Mahasarakham 44150 Thailand \\ ${ }^{2}$ Faculty of Natural Resources Rajamangala University of Technology Isan Sakonnakhon Campus, Sakonnakhon 47160 \\ Thailand \\ ${ }^{3}$ Department of crop and soil sciences, Faculty of Agriculture, Botswana University of Agriculture and Natural \\ Resources, Gaborone Botswana
}

*Corresponding author: darika.bu@msu.ac.th

\begin{abstract}
The aim of this research was to investigate the effect of sulphur (S) on growth, agricultural traits, seed yield and oil content in white, brown and black seed color of sesame grown under infertile soil. The experiment was conducted in RCBD arranged in factorial $3 \times 4$ with 3 reps under pot condition both dry and wet season; factor A was 3 cultivars of sesame and factor B was 4 levels of sulfur (S). The results showed that various cultivars of sesame responded differently to $\mathrm{S}$ levels. Some agronomic traits were not affected by $\mathrm{S}$ levels i.e. plant height, SCMR and 1000 seeds weight especially in wet season but these traits differed in various cultivars of sesame. Combined analysis of the two seasons was also done and the results showed that $\mathrm{S}$ levels did not affect to most traits except number of capsules, whereas interaction between cultivar and $\mathrm{S}$ level were found on number of branches, total dry weight and oil content, cv. KKU2 and KKU3 (black and brown seed). cv. KKU3 with application of S at $20 \mathrm{~kg} \mathrm{ha}^{-1}$ showed highest total dry weight, whereas cv. KKU3 with application rate of $\mathrm{S}$ at $0 \mathrm{~kg} \mathrm{ha}^{-1}$ showed highest oil content followed by cv. MK60 with $80 \mathrm{~kg} \mathrm{ha}^{-1}$. Interestingly the black and brown seeded cultivars had a positive response to $S$ levels as compared to the white seeded cultivar. From the result, we can conclude that the dry season is the optimal season for sesame production in low fertile soils and that black and brown seed color responds positive to $S$ level than white. However, we strongly suggest that field study should be undertaken to correlate our results in natural growing conditions.
\end{abstract}

Keywords: sulphur application, infertile soils, oil seed, S/R ratio, percent of oil.

Abbreviations: S_sulphur; OM_organic matter; EC_electrical conductivity; RCB_randomized complete block design; DAP_days after planting; SCMR_Spad chlorophyll meter reading.

\section{Introduction}

Sesamum indicum L. commonly known as sesame is an important oilseed crop (Cui et al., 2021) which belongs to the family Pedaliaceae and is thought to be the oldest oilseed used by human beings (Pal et al., 2020). Sesame is widely grown in Africa and Asia for its high-quality nutritional seeds (Dossa et al., 2017), edible oil and use as food (Walcal et al., 2021). Generally, sesame grows in rainfed conditions, from arid to semi-arid regions (Jiang et al., 2009; Pathak et al., 2014). Sesame is a versatile crop with high quality edible oil with diverse usage (Ahmad et al., 2018), among the oil seed crops, sesame has the highest oil content at $46-64 \%$ with $25 \%$ protein (Wei et al., 2015), and it also contains vitamins, amino acids and polyunsaturated fatty acids, various unsaturated fatty acids (i.e. linoleic and oleic acids) that are mainly responsible for oil quality (Uzun et al., 2008). However, the production of oil seed crops including sesame is still very low and far from meeting the worldwide demand. Low production of sesame is attributed production under rainfed condition, marginal land and less fertile soil, moreover, oil seed crops are particularly sensitive to $S$ deficiency because $S$ is essential for their growth and capsule formation. $S$ is considered as the fourth main plant nutrient after nitrogen $(\mathrm{N})$, phosphorus $(\mathrm{P})$ and potassium $(\mathrm{K})$, and its low availability in various soils causes the innate $S$ deficiency. High yield and quality of oilseed crops are possible only when crops grown with optimum amount of $S$ in the growth medium (Scherer, 2001) because $S$ plays a key role in the plant metabolism, indispensable for the synthesis of essential oils, chlorophyll formation, cell development and it also increases cold resistance and drought hardiness of crops especially for oilseed crops (Patel and Shelke, 1995). In general, sufficient amount of $S$ application significantly 
increases crop growth and improves the quality of sesame by increasing protein and oil contents (Raja et al., 2007). Previously, studies about effect of $S$ on growth and yield of sesame have been reported, however these studies have not considered the fertility of the growth medium and mostly did not work with diverse genotypes. Therefore, the recent research focused on investigating the effects of $S$ on growth, seed and oil yield and their related traits in white, brown, and black colored seed of sesame cultivars grown under infertile soil in both wet and dry season.

\section{Results and discussion}

\section{Soil properties}

$\mathrm{N}$ content is very low $(0.0056 \%)$ in our soil, but available $\mathrm{K}$ is high (231.89 ppm) and available $P$ is medium (14.00 ppm). Organic matter is still low (1.496\%) whereas, EC value is normal (non-saline soil), $\mathrm{pH}$ is 7.6 and $\mathrm{S}$ content is $17.42 \mathrm{mg} \mathrm{kg}$ ${ }^{1}$ (Supp Table 1).

$\mathrm{S}$ content in soil before planting sesame was $17.42 \mathrm{mg} \mathrm{kg}^{-1}$ and after harvesting sesame $\mathrm{S}$ content contains in soil higher than $17.42 \mathrm{mg} \mathrm{kg}^{-1}, \mathrm{~S}$ content contains in soil is lower than $17.42 \mathrm{mg}$ $\mathrm{kg}^{-1}$ in all treatment combination (Supp Table 2).

\section{Meteorological data}

The climate of the research area was semi-arid. The data were recorded between January to December 2020. Average temperature ranged between 24.2 to 32.2 ㅇ (Supp Fig. 1), a yearly rainfall was $1262.3 \mathrm{~mm}$ and August had the highest monthly rainfall $(247.0 \mathrm{~mm}$ ) (Supp Fig. 2), relative humidity ranged between $64-83 \%$ and evaporation ranged between 3.3-5.8 $\mathrm{mm}^{-1}$ day $^{-1}$ (Supp Fig. 3).

Effect of sesame cultivars and S treatments on growth, seed and oil yield parameters content under two seasons

\section{Growth Parameters}

In dry season, the cultivar effect on plant height was significantly different at late growth days but no significant difference was observed in earlier growth days, however, analysis on effect of $\mathrm{S}$ levels, interaction of $\mathrm{S}$ and cultivar showed no significance difference on plant height (Table 1). Whereas in wet season, the cultivar effect on plant height showed significant difference throughout growth days, but the levels of $S$ did not have any effect on plant height except at 90 DAP. Interaction between cultivar and levels of $S$ had mixed results throughout the growth period (Table 2). Similar results were observed by Parmar et al. (2018); Kalegore et al. (2018) who reported that $S$ levels had no effect on plant height, but contrarily Tahir et al. (2014) and Paul et al. (2019) found out that $S$ levels had an effect on plant height

Observation into the number of branches showed that the cultivar effect had a highly significant difference throughout the growing days during both growing seasons. However, levels of $S$, cultivar $x \mathrm{~S}$ interaction had no effect on the number of branches for both the seasons (Table 1 ) except only at 90DAP during the wet seasons where a significant difference was observed as an effect of $\mathrm{S}$ recording a higher number of branches with addition of $S$ at rate $20 \mathrm{~kg} \mathrm{ha}^{-1}$ (Table 2). Our results are similar to Kalegare et al. (2018); Parmar et al. (2018) who found that $S$ levels did not affect number of branches, on the other hand, Ahmad et al. (2018) found that S levels had an effect on number of branches and suggested that sulfur enhanced the metabolic and meristematic activities of crop resulting with increase in branches plant ${ }^{-1}$.

\section{Chlorophyll content}

In both seasons, the Spad chlorophyll meter reading (SCMR) showed highly significant different results as influenced by cultivar throughout the growing season. However, for the dry season the levels of $S$, cultivar $x \mathrm{~S}$ interaction did not have effect on SCMR except at 75 DAP where a highly significant difference was observed (Table 3). In wet season, the levels of $S$ had no effect on SCMR (Table 4) whereas the cultivar $x \mathrm{~S}$ interaction only showed significant difference at 45 DAP and the rest of the growing days there was no significant difference observed.

The results showed that the cultivars effect had high significant difference on chlorophyll content through the growing days for both the seasons. cV. MK60 recorded higher chlorophyll content followed by cv. KKU2 and KKU3 (Table 3 \& 4). When we considered $S$ levels, cultivar $\times S$ interaction we found the only significant difference at 75 DAP where $S$ at $40 \mathrm{~kg} \mathrm{ha}^{-1}$ had higher chlorophyll content $\left(3.00 \mu \mathrm{g} \mathrm{cm}^{-2}\right)$ during the dry season (Table 5). In wet season, the $S$ levels did not have effect on chlorophyll content except at $45 \mathrm{DAP}, 80 \mathrm{~kg} \mathrm{ha}^{-1}$ of $\mathrm{S}$ showed higher chlorophyll content than other levels $\left(1.24 \mu \mathrm{g} \mathrm{cm}^{-2}\right)$. Similar for interaction, no significant difference was observed except at 45 DAP (Table 4).

\section{Yield (Seed and oil) and yield related traits}

Observation in the dry season, showed that number of capsules plant $^{-1}$ were significantly different among the sesame cultivars at 60 and 75 DAP with cv. MK60 having highest number of capsules at 2.7 and 23.8 capsules, respectively. No significant difference was observed at 90 DAP (Table 5), whereas $S$ levels influenced the number of capsules plant ${ }^{-1}$ at 60,75 and 90 DAP. An interesting result was observed where 0 $\mathrm{kg} \mathrm{ha}^{-1}$ of $\mathrm{S}$ recorded higher capsules with average of 1.4, 23.5 and 30.1 capsules at 60,75 and 90 DAP respectively (Table 5). Also, a highly significant interaction between cultivar and $S$ levels was noted.

During the wet season, cv. MK60 and KKU3 showed highest number of capsules at 60, 75 and $90 \operatorname{DAP}(7.6,14.2,14.7$, and $8.4,13.7,15.2$ capsules, respectively). The levels of $S$ had an effect on number of capsules only at 60 DAP while at 75 and 90 DAT no significant difference was recorded, with $S$ at 40 and $80 \mathrm{~kg} \mathrm{ha}^{-1}$ recording higher capsules than other rates (8.6 and 7.8 capsules, respectively) (Table 6). Raza et al. (2018a) and Ahmad et al. (2018) reported that $S$ levels influenced number of capsules plant ${ }^{-1}$ and Paul et al. (2019) and Khan et al. (2016) reported that lower $\mathrm{S}$ levels had higher number of capsules as compared to higher application rate of $\mathrm{S}$. Whether the higher or lower application rate of $\mathrm{S}$ gives more capsules is still under intensive studies with some reports suggesting higher levels gave higher number of capsules (Tahir et al., 2014), whereas Parmar et al. (2018) and Kalegore et al. (2018) had contrasting results and found lower $\mathrm{S}$ levels did not have effect on number of capsules. Contrarily, results of our study in the dry season shows that low levels of $S$ recorded the highest number of capsules. 


\section{Seed weight $\left(g p \Gamma^{1}\right)$}

Both the cultivar and levels of $S$ influenced the seed weight of sesame in the dry season (Table 5), thus a highly significant difference was also observed in the interaction of the cultivar and $\mathrm{S}$ levels. The result revealed that $\mathrm{cv}$. KK3 had higher seed weight than other cultivars $\left(4.53 \mathrm{~g} \mathrm{pl}^{-1}\right)$ following $\mathrm{cv}$. MK60 and KKU2 (3.89 and $3.77 \mathrm{~g} \mathrm{pl}^{-1}$, respectively). Application of $\mathrm{S}$ at $\mathrm{S}$ 20 and $40 \mathrm{~kg} \mathrm{ha}^{-1}$ showed higher seed weight than other application rates (4.65 and $4.28 \mathrm{~g} \mathrm{pl}^{-1}$ respectively) (Table 5). In wet season, cv. KKU3 and cV. MK60 recorded a similar seed weight of $2.00 \mathrm{~g} \mathrm{pl}^{-1}$, which was higher than $\mathrm{cv}$. KKU2 at $1.53 \mathrm{~g}$ $\mathrm{pl}^{-1}$. Results of $\mathrm{S}$ levels showed no effect on seed weight and this result contrasts with dry season results (Table 6). Raza et al. (2018a) and Paul et al. (2019) reported that S levels influenced seed weight with application of 30 and $40 \mathrm{~kg} \mathrm{ha}^{-1}$ of $S$ recording the highest seed weight, these results are similar to ours in dry season but contrasting with our wet season results. Our wet season results are in line with Kalegore et al. (2018) and Parmar et al. (2018) who did not find the effect of $S$ levels on seed weight plant ${ }^{-1}$.

\section{Thousand seed weight (g)}

Both the dry season and wet season showed that 1000 seed weight was not affected by cultivar, $\mathrm{S}$ level or the interaction of the two. (Table $5 \& 6$ ). These results are supported by Paul et al. (2019); Khan et al. (2016) and Murma (2015) who reported that $\mathrm{S}$ levels did not have effect on thousand seed weight. Contrarily, Tahir et al. (2014) and Shah et al. (2013) who reported that thousand seed weight was significantly influence by $S$ levels. Our results showed that interaction of $S$ level and cultivar also did not have any effect of 1000 seed weight which is contrary to Paul et al. (2019) who reported high interaction between cultivar and S levels.

\section{Oil content $(w / w)$}

During the dry season, cultivars and interaction of cultivars and $S$ levels had no effect on oil content, however, levels of $S$ showed a significant difference with application of $S$ at $80 \mathrm{~kg}$ $\mathrm{ha}^{-1}$ recording higher oil content $(50.01 \%)$ than other rates followed by 0,40 and $20 \mathrm{~kg} \mathrm{ha}^{-1}(46.31,41.71$ and $39.69 \%$, respectively) (Table 5). In wet season, an interesting result was observed where cv. KKU2 and cV. KKU3 recorded higher oil content (51.37 and 52.43\%, respectively) than cV. MK60 (43.91\%). Our results differed with Akinoso et al. (2010) who reported that brown seed had higher oil content than black seed sesame but in our study no significant difference was observed between the black and brown colored seed (Table 6). In the wet season observation showed that cultivar and levels of $S$ had an effect on the oil content whereas the $S$ levels effect did not have any influence on the oil content. Contrasting results were observed by Tahir et al. (2014); Paul et al. (2019); Ahmad et al. (2018) and Raza et al. (2018a), who reported found the $S$ levels to have an effect on the oil yield of sesame.

\section{Dry matter analysis}

\section{Shoot dry weight $\left(g \mathrm{p}^{1}\right)$}

The highest Shoot dry weight (SDW) was observed in KKU3 at $4.78 \mathrm{~g} \mathrm{pl}^{-1}$ for the dry season and KKU2 at $5.48 \mathrm{~g} \mathrm{pl}^{-1}$ for the wet season. The results of the S levels on SDW showed that 20 $\mathrm{kg} \mathrm{ha}^{-1}$ had the highest weight at $4.37 \mathrm{~g} \mathrm{pl}^{-1}$ for the dry season whereas for the wet season there was no significant difference among the levels (Table 7 and 8). Analysis on the interaction of cultivar and $\mathrm{S}$ levels on SDW showed highly significant difference during the dry season but for the wet season no significant difference was recorded. Not so many previous studies have taken consideration of this parameter as few have reported on it like Islam et al. (2019) who reported that $S$ and Zinc (Z) did not have effect on shoot dry weight at 35 DAP but some effect was observed at 45 and 60 DAP.

\section{Leaf dry weight $\left(g \mathrm{p} \Gamma^{1}\right)$}

The only difference in leaf dry weight (LDW) observed in the wet season was influenced by the cultivar, whereas the factors did not have any effect on the LDW in any of the two seasons. The highest LDW was recorded in KKU2, followed by KKU3 and MK60 at 2.26, 0.90 and $0.65 \mathrm{~g} \mathrm{pl}^{-1}$ respectively during the wet season.

\section{Total dry matter $\left(g p \Gamma^{1}\right)$}

During the dry season, the highest total dry matter (TDM) was recorded at $10.65 \mathrm{~g} \mathrm{pl}^{-1}$ for KKU3 cultivar with KKU2 recording the second highest weight. The $\mathrm{S}$ levels recorded significantly different results with $20 \mathrm{~kg} \mathrm{ha}^{-1}$ level recording the highest weight at $10.36 \mathrm{~g} \mathrm{pl}^{-1}$ followed by 40 and $80 \mathrm{~g} \mathrm{pl}^{-1}$ which recorded similar TDM. A highly significant effect was also observed in the interaction between cultivar and $\mathrm{S}$ levels for the TDM (Table 7).

In wet season, the cultivar influenced TDM as KKU2 recorded the highest weight of $10.57 \mathrm{~g} \mathrm{pl}^{-1}$ while the other two cultivars had similar weights. The $S$ levels and interaction of cultivar and $S$ levels did not have any influence the TDM during the wet season (Table 8). Our dry season results agree with Raza et al. (2018b) and Ahmad et al. (2018) who observed that S levels did affect the total dry weight. Higher TDM recorded at $20 \mathrm{~kg}$ $\mathrm{ha}^{-1}$ on our study is in contrast with Shah et al. (2013) who recorded higher TDM at $60 \mathrm{~kg} \mathrm{ha}^{-1}$ when compared to other rates. Similar to our wet season results Kalegore et al., (2018) found out that $\mathrm{S}$ levels do not affect the TDM.

\section{Root dry weight $\left(g \mathrm{pr}^{1}\right)$}

Different application rates of $S$ were found to not affect the root dry weight (RDM) of sesame plant when grown in the dry season, whereas the cultivar, $\mathrm{S}$ level $\mathrm{x}$ cultivar interaction showed significant different results of RDM. KKU2 and KKU3 had the highest RDM at 2.91 and $2.71 \mathrm{~g} \mathrm{pl}^{-1}$ respectively (Table 7). In wet season, RDM was significantly different for cultivar and for the $\mathrm{S}$ levels but no significant difference was recorded for the interaction of cultivar $x \mathrm{~S}$ levels (Table 8). During the wet season application of $S$ at $20 \mathrm{~kg} \mathrm{ha}^{-1}$ gave the lowest RDM as compared to the other rates, contrarily when Islam et al., (2019) applied S at $18.0 \mathrm{~kg} \mathrm{ha}^{-1}$ they recorded higher RDM as compared to other treatments.

\section{Shoot/Root ratio (S/R ratio)}

In dry season, $S / R$ ratio showed significant different results among cultivars, levels of $S$, interaction of cultivar and $S$ levels. Among the cultivars MK60 had the highest $S / R$ ration at 2.90 while KKU2 had the lowest $S / R$ ratio at 1.72 . The results of $S$ levels showed that application of $20 \mathrm{~kg} \mathrm{ha}^{-1}$ had higher $S / R$ ratio while the rest of the application rates had statistically similar results (Table 7). In wet season, the result for all the 
Table 1. Growth parameters of various sesame cultivars and levels of $S$ under dry season.

\begin{tabular}{|c|c|c|c|c|c|c|c|c|}
\hline & & & Plant he & & & & er of bran & Jlant $^{-1}$ \\
\hline & 30 DAP & 45 DAP & 60 DAP & 75 DAP & 90 DAP & 60 DAP & 75 DAP & $90 \mathrm{DAP}$ \\
\hline Cultiva & & & & & & & & \\
\hline MK60 & 14.58 & 39.60 & $63.71 b$ & $64.55 b$ & $66.23 b$ & $1.5 b$ & $1.5 b$ & $1.6 b$ \\
\hline KKU2 & 15.62 & 40.86 & $70.84 a$ & 74.91a & $76.15 a$ & $3.0 a$ & $3.2 a$ & $3.2 a$ \\
\hline KKU3 & 14.35 & 39.16 & $72.98 a$ & $77.30 \mathrm{a}$ & $77.94 a$ & $3.0 a$ & $3.3 a$ & $3.3 a$ \\
\hline F-test & ns & ns & $* *$ & $* *$ & $* *$ & $* *$ & $* *$ & $* *$ \\
\hline LSD & - & - & 5.59 & 4.89 & 5.35 & 0.49 & 0.56 & 0.59 \\
\hline $\mathrm{S}(\mathrm{S})(\mathrm{k}$ & & & & & & & & \\
\hline 0 & 15.47 & 40.57 & 67.3 & 72.14 & 72.57 & 2.5 & 2.8 & 2.8 \\
\hline 20 & 15.19 & 41.37 & 69.51 & 72.22 & 73.09 & 2.5 & 2.7 & 2.7 \\
\hline 40 & 15.53 & 40.72 & 70.22 & 72.37 & 74.17 & 2.4 & 2.6 & 2.6 \\
\hline 80 & 13.21 & 36.83 & 69.68 & 72.28 & 73.93 & 2.5 & 2.6 & 2.6 \\
\hline F-test & ns & ns & ns & ns & ns & ns & ns & ns \\
\hline $\mathrm{C} * \mathrm{~S}$ & ns & ns & ns & ns & ns & ns & ns & ns \\
\hline CV (\%) & 15.73 & 17.96 & 9.56 & 8.01 & 8.62 & 23.24 & 24.55 & 17.95 \\
\hline
\end{tabular}

ns= non-significant, $*$ and $* *=$ significant at $\alpha=0.01$.

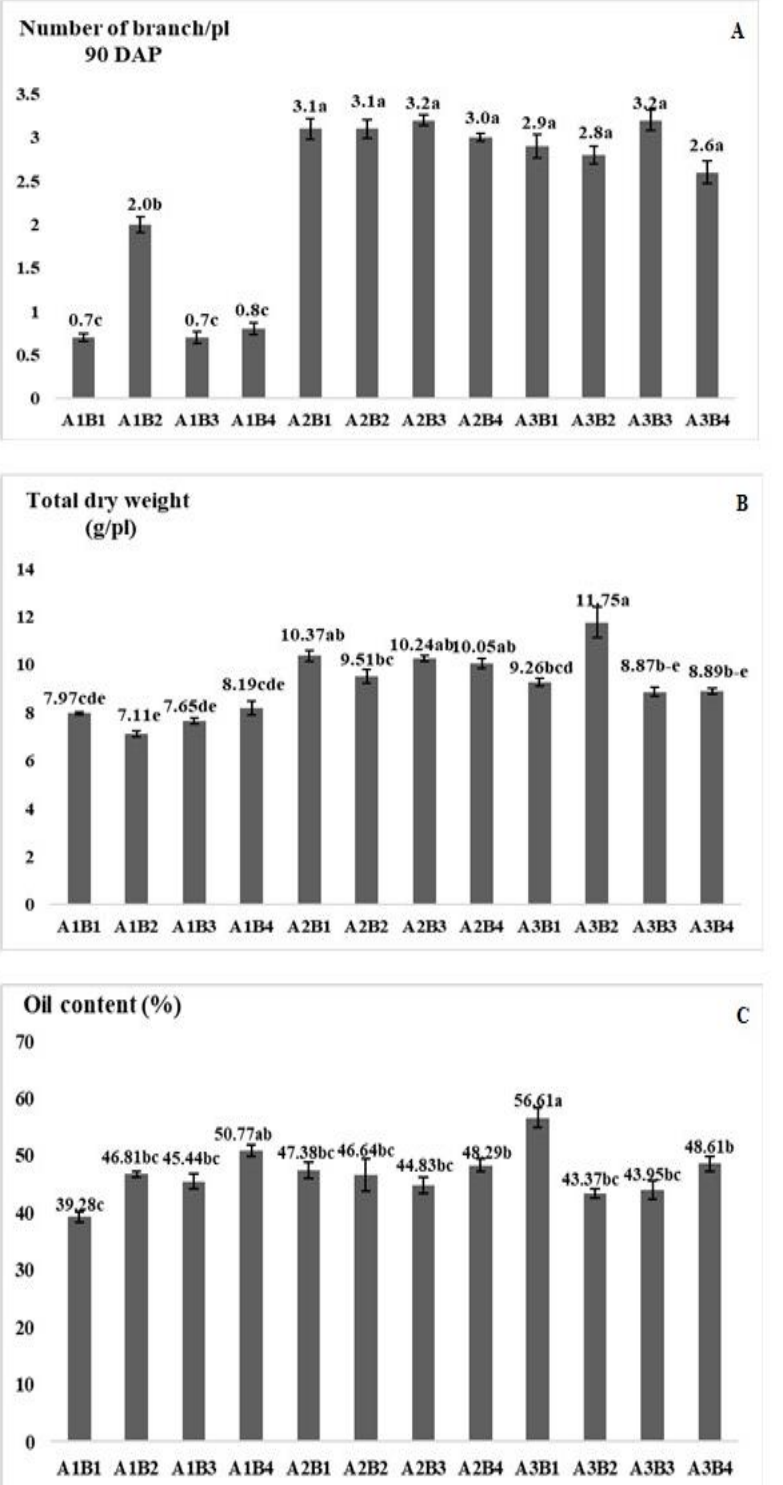

Fig 1. Combined analysis on number of branches per plant (A), total dry weight (B) and oil content (C) among various sesame cultivars and levels of S (compare mean by LSD method). 
Table 2. Growth parameters of various sesame cultivars and levels of $\mathrm{S}$ under wet season.

\begin{tabular}{|c|c|c|c|c|c|c|c|c|}
\hline & \multicolumn{5}{|c|}{ Plant height } & \multicolumn{3}{|c|}{ Number of branches/plant } \\
\hline & 30 DAP & 45 DAP & 60 DAP & 75 DAP & 90 DAP & 60 DAP & 75 DAP & 90 DAP \\
\hline \multicolumn{9}{|c|}{ Cultivar (C) } \\
\hline MK60 & $33.88 b$ & $59.46 b$ & $87.44 c$ & $100.48 b$ & $103.78 c$ & $0.9 c$ & $1.0 \mathrm{~b}$ & $0.5 c$ \\
\hline KKU2 & $39.58 a$ & $66.33 a$ & $92.59 b$ & $118.12 \mathrm{a}$ & 129.76a & $1.6 b$ & $2.6 a$ & 3.0a \\
\hline KKU3 & $40.06 a$ & $67.79 a$ & $99.10 a$ & $116.00 \mathrm{a}$ & $119.29 c$ & $2.1 \mathrm{a}$ & $2.4 a$ & $2.5 b$ \\
\hline F-test & $* *$ & $* *$ & $* *$ & $* *$ & $* *$ & $* *$ & $* *$ & $* *$ \\
\hline LSD & 1.27 & 3.07 & 4.53 & 5.7 & 7.61 & 0.33 & 0.41 & 0.4 \\
\hline \multicolumn{9}{|c|}{$\mathrm{S}(\mathrm{S})\left(\mathrm{kg} \mathrm{ha}^{-1}\right)$} \\
\hline 0 & 38.26 & 65.19 & 94.02 & 114.61 & $119.40 \mathrm{ab}$ & 1.8 & 1.9 & $1.7 \mathrm{~b}$ \\
\hline 20 & 38.21 & 64.49 & 91.09 & 109.73 & $113.72 b$ & 1.4 & 2.1 & $2.6 a$ \\
\hline 40 & 37.31 & 64.5 & 93.61 & 109.12 & $112.56 b$ & 1.5 & 2.3 & $2.1 b$ \\
\hline 80 & 37.59 & 63.93 & 93.44 & 112.67 & $124.76 a$ & 1.4 & 1.6 & $1.6 \mathrm{~b}$ \\
\hline F-test & ns & ns & ns & ns & $*$ & ns & ns & $*$ \\
\hline LSD & & & & & & & & 0.24 \\
\hline$C^{*} S$ & $*$ & ns & ns & $*$ & ns & ns & ns & ns \\
\hline CV (\%) & 3.98 & 5.61 & 5.75 & 6.03 & 7.64 & 25.5 & 24.64 & 21.39 \\
\hline
\end{tabular}

ns $=$ non-significant, ${ }^{*}$ and ${ }^{* *}=$ significant at $\alpha=0.05$ and 0.01 , respectively.

Table 3. Chlorophyll analysis of various sesame cultivars and levels of $\mathrm{S}$ under dry season.

\begin{tabular}{|c|c|c|c|c|c|c|}
\hline & \multicolumn{3}{|c|}{ SCMR } & \multicolumn{3}{|c|}{ Chlorophyll content $\left(\mu \mathrm{gcm}^{-2}\right)$} \\
\hline & 45 DAP & 60 DAP & 75 DAP & 45 DAP & 60 DAP & 75 DAP \\
\hline \multicolumn{7}{|c|}{ Cultivar (C) } \\
\hline MK60 & $57.65 a$ & $51.94 a$ & 18.63ab & $8.63 a$ & $7.60 a$ & $2.17 a$ \\
\hline KKU2 & $48.55 b$ & $41.16 b$ & $15.19 b$ & $6.22 b$ & $5.16 \mathrm{~b}$ & $1.80 \mathrm{~b}$ \\
\hline KKU3 & $47.23 b$ & $37.55 c$ & $20.66 a$ & $6.31 b$ & $5.15 b$ & $1.76 b$ \\
\hline F-test & $* *$ & $* *$ & $* *$ & $* *$ & $* *$ & $*$ \\
\hline LSD & 2.35 & 2.48 & 4.11 & 0.8 & 0.87 & 0.35 \\
\hline \multicolumn{7}{|c|}{$\mathrm{S}\left(\mathrm{kg} \mathrm{ha}^{-1}\right)$} \\
\hline 0 & 51.82 & 43.6 & $16.71 b$ & 7.31 & 6.38 & $1.76 b$ \\
\hline 20 & 51.85 & 44.18 & $20.62 a b$ & 7.19 & 5.92 & $1.71 b$ \\
\hline 40 & 50.87 & 44.73 & $23.87 a$ & 6.92 & 6.42 & $3.00 a$ \\
\hline 80 & 50.3 & 41.68 & $11.44 \mathrm{c}$ & 6.79 & 5.15 & $1.21 \mathrm{c}$ \\
\hline F-test & ns & ns & $* *$ & ns & ns & $* *$ \\
\hline LSD & - & - & 4.75 & - & - & 0.86 \\
\hline $\mathrm{C}^{*} \mathrm{~S}$ & ns & ns & $* *$ & ns & ns & $* *$ \\
\hline CV (\%) & 5.41 & 6.74 & 12.83 & 13.33 & 17.14 & 21.76 \\
\hline
\end{tabular}

Table 4. Chlorophyll analysis of various sesame cultivars and levels of $\mathrm{S}$ under wet season.

\begin{tabular}{|c|c|c|c|c|c|c|}
\hline & \multicolumn{3}{|c|}{ SCMR } & \multicolumn{3}{|c|}{ Chlorophyll content $\left(\mu \mathrm{g} \mathrm{cm}^{-2}\right)$} \\
\hline & 45 DAP & 60 DAP & 75 DAP & 45 DAP & 60 DAP & 75 DAP \\
\hline \multicolumn{7}{|c|}{ Cultivar (C) } \\
\hline MK60 & $45.53 a$ & $46.62 a$ & $36.76 a$ & $0.75 b$ & $6.86 a$ & $4.12 a$ \\
\hline KKU2 & $40.17 c$ & $39.78 b$ & $30.84 b$ & $1.19 a$ & $5.19 \mathrm{~b}$ & $3.31 b$ \\
\hline KKU3 & $41.90 b$ & $40.06 b$ & 31.87 & $0.90 b$ & $5.34 b$ & $3.71 \mathrm{ab}$ \\
\hline F-test & $* *$ & $* *$ & $* *$ & $* *$ & $* *$ & $*$ \\
\hline LSD & 1.31 & 1.61 & 2.78 & 0.19 & 0.60 & 0.59 \\
\hline \multicolumn{7}{|c|}{$\mathrm{S}(\mathrm{S})\left(\mathrm{kg} \mathrm{ha}^{-1}\right)$} \\
\hline 0 & 42.1 & 41.92 & 32.99 & $0.84 b$ & 5.94 & 3.57 \\
\hline 20 & 42.5 & 42.37 & 33.39 & $0.96 b$ & 5.66 & 3.87 \\
\hline 40 & 43.08 & 42.08 & 31.87 & $0.76 b$ & 6.05 & 3.82 \\
\hline 80 & 42.47 & 42.24 & 34.38 & $1.24 a$ & 5.54 & 3.59 \\
\hline F-test & ns & ns & ns & $* *$ & ns & ns \\
\hline LSD & - & - & - & 0.37 & - & - \\
\hline C*S & $*$ & ns & ns & $* *$ & ns & ns \\
\hline CV (\%) & 3.64 & 4.50 & 9.90 & 17.53 & 12.23 & 18.61 \\
\hline
\end{tabular}

ns $=$ non-significant, ${ }^{*}$ and ${ }^{* *}=$ significant at $\alpha=0.05$ and 0.01 , respectively. 
Table 5. Seed and oil yield and yield related traits of various sesame cultivars and levels of S under dry season.

\begin{tabular}{|c|c|c|c|c|c|c|}
\hline & \multicolumn{3}{|c|}{ Number of capsules $\mathrm{pl}^{-1}$} & \multirow[t]{2}{*}{ Seed weight $\left(\mathrm{g} \mathrm{pl}^{-1}\right)$} & \multirow[t]{2}{*}{1000 seed weight } & \multirow[t]{2}{*}{ Oil content } \\
\hline & 60 DAP & 75 DAP & 90 DAP & & & \\
\hline \multicolumn{7}{|c|}{ Cultivar (C) } \\
\hline MK60 & $2.7 a$ & $23.8 a$ & 25.6 & $3.89 \mathrm{~b}$ & 2.72 & 47.24 \\
\hline KKU2 & $0.5 b$ & $20.0 b$ & 26 & $3.77 b$ & 2.80 & 42.21 \\
\hline KKU3 & $0.5 b$ & $19.3 b$ & 27.9 & $4.53 a$ & 2.87 & 43.83 \\
\hline F-test & $* *$ & $* *$ & ns & $*$ & ns & ns \\
\hline LSD & 0.29 & 1.71 & - & 0.51 & & \\
\hline \multicolumn{7}{|c|}{$\mathrm{S}\left(\mathrm{kg} \mathrm{ha}^{-1}\right)$} \\
\hline 0 & $1.4 a b$ & $23.5 a$ & $30.1 a$ & $3.69 b c$ & 2.74 & $46.31 a b$ \\
\hline 20 & $1.7 a$ & $19.5 c$ & $27.9 a$ & $4.65 a$ & 2.87 & $39.69 c$ \\
\hline 40 & $1.4 b$ & $21.5 b$ & $24.2 b$ & $4.28 a b$ & 2.79 & $41.71 b c$ \\
\hline 80 & $0.6 c$ & $19.4 c$ & $23.9 b$ & $3.64 c$ & 2.79 & $50.01 a$ \\
\hline F-test & $* *$ & $* *$ & $* *$ & $* *$ & ns & $* *$ \\
\hline LSD & 0.34 & 1.97 & 2.88 & 0.59 & - & 5.77 \\
\hline$C^{*} S$ & $* *$ & $* *$ & $* *$ & $* *$ & ns & ns \\
\hline CV (\%) & 21.96 & 9.63 & 11.12 & 14.87 & 6.19 & 13.28 \\
\hline
\end{tabular}

Table 6. Seed and oil yield and yield related traits of various sesame cultivars and levels of S under wet season.

\begin{tabular}{|c|c|c|c|c|c|c|}
\hline & \multicolumn{3}{|c|}{ Number of capsules $\mathrm{pl}^{-1}$} & \multirow[t]{2}{*}{ Seed weight $(\mathrm{g} / \mathrm{pl})$} & \multirow[t]{2}{*}{1000 seed weight } & \multirow[t]{2}{*}{ Oil content } \\
\hline & 60 DAP & 75 DAP & 90 DAP & & & \\
\hline \multicolumn{7}{|c|}{ Cultivar (C) } \\
\hline MK60 & $7.6 a$ & $14.2 a$ & $14.7 a$ & $2.00 a$ & 2.80 & $43.91 b$ \\
\hline KKU2 & $4.6 b$ & $8.4 \mathrm{~b}$ & $11.5 b$ & $1.53 b$ & 3.00 & $51.37 a$ \\
\hline KKU3 & $8.4 a$ & $13.7 a$ & $15.2 \mathrm{a}$ & $2.00 a$ & 2.94 & $52.43 a$ \\
\hline F-test & $* *$ & $* *$ & $* *$ & $* *$ & ns & $* *$ \\
\hline LSD & 1.00 & 1.53 & 1.67 & 0.21 & - & 5.20 \\
\hline \multicolumn{7}{|c|}{$\mathrm{S}\left(\mathrm{kg} \mathrm{ha}^{-1}\right)$} \\
\hline 0 & $4.9 c$ & 11.7 & 13.8 & 1.92 & 3.01 & 49.21 \\
\hline 20 & $8.6 a$ & 12.4 & 13.7 & 1.83 & 2.82 & 51.52 \\
\hline 40 & $6.2 b$ & 11.6 & 13.4 & 1.87 & 3.04 & 47.78 \\
\hline 80 & $7.8 a$ & 12.7 & 14.2 & 1.7 & 2.79 & 48.44 \\
\hline F-test & $* *$ & ns & ns & ns & ns & ns \\
\hline LSD & 1.16 & - & - & - & - & - \\
\hline$C^{*} S$ & $* *$ & ns & ns & ns & ns & $* *$ \\
\hline CV (\%) & 17.20 & 14.96 & 14.44 & 13.4 & 7.86 & 12.48 \\
\hline
\end{tabular}

Table 7. Dry matter analysis of various sesame cultivars and levels of $\mathrm{S}$ under dry season.

\begin{tabular}{|c|c|c|c|c|c|c|}
\hline & $\begin{array}{l}\text { Shoot dry weight } \\
\left(\mathrm{g} \mathrm{pl}^{-1}\right)\end{array}$ & $\begin{array}{l}\text { Leaf dry weight } \\
\left(\mathrm{g} \mathrm{pl}^{-1}\right)\end{array}$ & $\begin{array}{l}\text { Total dry matter } \\
\left(\mathrm{g} \mathrm{pl}^{-1}\right)\end{array}$ & $\begin{array}{l}\text { Root dry weight } \\
\left(\mathrm{g} \mathrm{pl}^{-1}\right)\end{array}$ & $S / R$ ratio & $\mathrm{HI}$ \\
\hline \multicolumn{7}{|c|}{ Cultivar (C) } \\
\hline MK60 & $2.59 c$ & 1.48 & $7.75 c$ & $0.92 b$ & $2.90 a$ & 0.49 \\
\hline KKU2 & $4.03 b$ & 1.68 & $9.52 b$ & $2.91 a$ & $1.72 \mathrm{c}$ & 0.43 \\
\hline KKU3 & $4.78 a$ & 1.45 & $10.65 a$ & $2.71 a$ & $2.29 b$ & 0.43 \\
\hline F-test & $* *$ & ns & $* *$ & $* *$ & $* *$ & ns \\
\hline LSD & 0.47 & - & 0.97 & 0.37 & 0.39 & - \\
\hline \multicolumn{7}{|c|}{$\mathrm{S}\left(\mathrm{kg} \mathrm{ha}^{-1}\right)$} \\
\hline 0 & $3.81 \mathrm{~b}$ & 1.45 & $9.35 a b$ & 2.21 & $2.11 b$ & 0.48 \\
\hline 20 & $4.37 a$ & 1.78 & $10.36 a$ & 2.14 & $2.83 a$ & 0.45 \\
\hline 40 & $3.66 \mathrm{~b}$ & 1.45 & $8.76 b$ & 2.46 & $2.20 \mathrm{~b}$ & 0.46 \\
\hline 80 & $3.35 b$ & 1.47 & $8.74 b$ & 1.90 & $2.06 \mathrm{~b}$ & 0.41 \\
\hline F-test & $* *$ & ns & $*$ & ns & $* *$ & ns \\
\hline LSD & 0.54 & - & 1.12 & - & 0.45 & - \\
\hline$C * S$ & $* *$ & ns & $* *$ & $* *$ & $* *$ & ns \\
\hline CV (\%) & 14.48 & 21.98 & 12.32 & 20.22 & 19.98 & 13.07 \\
\hline
\end{tabular}

ns= non-significant, ${ }^{*}$ and $* *$ significant at $\alpha=0.05$ and 0.01 , respectively. 
Table 8. Dry matter analysis of various sesame cultivars and levels of $S$ under wet season.

\begin{tabular}{|c|c|c|c|c|c|c|}
\hline & $\begin{array}{l}\text { Shoot dry weight } \\
\left(\mathrm{g} \mathrm{pl}^{-1}\right)\end{array}$ & $\begin{array}{l}\text { Leaf dry weight } \\
\left(\mathrm{g} \mathrm{pl}^{-1}\right)\end{array}$ & $\begin{array}{l}\text { Total dry matter } \\
\left(\mathrm{g} \mathrm{pl}^{-1}\right)\end{array}$ & $\begin{array}{l}\text { Root dry weight } \\
\left(\mathrm{g} \mathrm{pl}^{-1}\right)\end{array}$ & $S / R$ ratio & $\mathrm{HI}$ \\
\hline \multicolumn{7}{|c|}{ Cultivar (C) } \\
\hline MK60 & $3.22 c$ & $0.65 c$ & $7.71 b$ & $0.62 c$ & 5.38 & $0.27 a$ \\
\hline KKU2 & $5.48 a$ & $2.26 a$ & $10.57 a$ & $1.09 a$ & 4.9 & $0.15 b$ \\
\hline KKU3 & $4.17 b$ & $0.90 b$ & $8.73 b$ & $0.76 b$ & 5.54 & $0.25 a$ \\
\hline F-test & $* *$ & $* *$ & $* *$ & $* *$ & ns & $* *$ \\
\hline LSD & 0.47 & 0.22 & 1.18 & 0.11 & - & 0.03 \\
\hline \multicolumn{7}{|c|}{$\left.\mathrm{S}\left(\mathrm{kg} \mathrm{ha}^{-1}\right)\right)$} \\
\hline 0 & 4.39 & 1.26 & 9.04 & $0.91 a$ & 5.05 & 0.23 \\
\hline 20 & 4.27 & 1.29 & 8.55 & $0.65 b$ & 5.88 & 0.22 \\
\hline 40 & 4.1 & 1.10 & 9.08 & $0.91 a$ & 4.99 & 0.21 \\
\hline 80 & 4.39 & 1.43 & 9.35 & $0.83 a$ & 5.17 & 0.22 \\
\hline F-test & ns & ns & ns & $* *$ & ns & ns \\
\hline LSD & - & - & - & 0.13 & - & - \\
\hline $\mathrm{C} * \mathrm{~S}$ & ns & ns & ns & ns & ns & ns \\
\hline CV (\%) & 13.09 & 20.64 & 15.52 & 15.8 & 20.87 & 14.37 \\
\hline
\end{tabular}

ns $=$ non-significant, ${ }^{*}$ and ${ }^{* *}=$ significant at $\alpha=0.05$ and 0.01 , respectively.

Table 9. Combined analysis of growth and yield parameters of various sesame cultivars and levels of $S$ for the two seasons.

\begin{tabular}{|c|c|c|c|c|c|c|}
\hline & $\begin{array}{l}\text { Plant height } \\
90 \text { DAP }\end{array}$ & $\begin{array}{l}\text { Number of } \\
\text { branch/pl } \\
90 \text { DAP }\end{array}$ & $\begin{array}{l}\text { Number of } \\
\text { capsule/pl } \\
60 \text { DAP }\end{array}$ & $\begin{array}{l}1000 \text { seed } \\
\text { weight }(g)\end{array}$ & $\begin{array}{l}\text { Total dry matter } \\
\text { (g/pl) }\end{array}$ & $\%$ Oil \\
\hline \multicolumn{7}{|l|}{ Cultivar (C) } \\
\hline MK60 & $85.00 \mathrm{~b}$ & $1.0 \mathrm{~b}$ & $5.2 a$ & 2.76 & $7.73 b$ & 45.58 \\
\hline KKU2 & $102.94 a$ & $3.1 \mathrm{a}$ & $2.6 b$ & 2.9 & $10.04 a$ & 46.79 \\
\hline KKU3 & $98.61 a$ & $2.9 a$ & $5.2 a$ & 2.9 & $9.69 a$ & 48.13 \\
\hline F-test & $* *$ & $* *$ & $* *$ & ns & $* *$ & ns \\
\hline LSD & 5.08 & 0.41 & 0.67 & - & 1.08 & - \\
\hline \multicolumn{7}{|l|}{$\mathrm{S}\left(\mathrm{kg} \mathrm{ha}^{-1}\right)$} \\
\hline 0 & 95.99 & 2.2 & $3.2 \mathrm{c}$ & 2.87 & 9.20 & 47.76 \\
\hline 20 & 93.40 & 2.6 & $5.2 a$ & 2.84 & 9.45 & 45.60 \\
\hline 40 & 93.36 & 2.40 & $3.7 \mathrm{bc}$ & 2.91 & 8.92 & 44.74 \\
\hline 80 & 99.33 & 2.1 & $4.2 \mathrm{~b}$ & 2.79 & 9.04 & 49.23 \\
\hline F-test & ns & ns & $* *$ & ns & ns & ns \\
\hline LSD & - & - & 0.69 & - & - & - \\
\hline C*S & ns & $*$ & ns & ns & $*$ & $* *$ \\
\hline$C V(\%)\left(S^{*} R^{*} A\right)$ & 7.99 & 26.43 & 24.92 & 7.02 & 17.73 & 14.9 \\
\hline$C V(\%)\left(S^{*} R^{*} A^{*} B\right)$ & 8.19 & 25.09 & 25.49 & 7.46 & 15.89 & 14.4 \\
\hline
\end{tabular}

ns $=$ non-significant, ${ }^{*}$ and ${ }^{* *}=$ significant at $\alpha=0.05$ and 0.01 , respectively.

factors showed no significant differences on the $S / R$ ration (Table 10).

\section{Harvest index (HI)}

Harvest index (HI) results showed that the parameter was not affected by all the studied factors during the dry season (Table 7). In wet season, significant differences were only observed among the cultivars where MK60 and KKU3 recorded the highest $\mathrm{HI}$ index at 0.27 and 0.25 (Table 8). The effect of $\mathrm{S}$ levels and interaction of $S$ levels $x$ cultivar showed no significant differences on the $\mathrm{HI}$ index. Our result disagreed with Paul et al. (2019); Shah et a. (2013) and Samant (2020) who reported that $\mathrm{S}$ levels influenced the $\mathrm{HI}$ index of sesame. However, Kalegore et al. (2018) supports our results as they found that the levels of $\mathrm{S}$ did not affect to $\mathrm{HI}$ index.

\section{Combined analysis between seasons}

A combined analysis for the growth, yield, yield related parameters was undertaken as per Gomez and Gomez (1984). The results showed that plant height showed that cultivar had a significant difference with KKU2 recording the highest plant height. The $\mathrm{S}$ level and interaction of $\mathrm{S}$ levels and cultivar showed no effect on the plant height (Table 9).

Number of branches $\mathrm{pl}^{-1}$ at $90 \mathrm{DAP}$, showed similar results as plant height where significant differences were observed among cultivar, but $S$ levels showed no influence on the number of branches. The cultivar with the higher number of branches was KKU2 at an average of 3.1 branches which was not statistically different from KKU3 at average of 2.9 branches. Black sesame (cv. KKU2) and brown sesame (cv. KKU3) had higher number of branches per plant at all levels of $S$ as compared to white seed sesame (cv. MK60) (Figure 4A). $\mathrm{cV}$. MK60 and KKU3 recorded the similar highest number of capsules $\mathrm{pl}^{-1}$ at 60 DAP with average of 5.2 capsules each and 
cV. KKU2 had a lower number of capsules at average of 2.6 capsules. The $S$ levels also had an influence on the number of capsules per plant with application rate of $20 \mathrm{~kg} \mathrm{ha}^{-1}$ recording the highest number as compared to the other application rates. An interaction between cultivar and levels of $S$ was not found in our study (Table 9).

Total dry matter $\left(\mathrm{g} \mathrm{pl}^{-1}\right)$ results show that $\mathrm{cV}$. KKU2 and KKU3 had the total dry matter at 10.04 and $9.69 \mathrm{~g} \mathrm{pl}^{-1}$ respectively. However, the level of $S$ did not have effect on the total dry matter. Interaction between cultivar and levels of $\mathrm{S}$ showed a significant difference for total dry matter suggesting that a combination of the two had an influence on the results (Table 9). The results showed that cV. KKU3 with application rate of $20 \mathrm{~kg} \mathrm{ha}^{-1}$ of $\mathrm{S}$ showed the highest total dry weight $\left(11.75 \mathrm{~g} \mathrm{pl}^{-}\right.$ $\left.{ }^{1}\right)$ followed by cv. KKU2 with $0 \mathrm{~kg} \mathrm{ha}^{-1}$ of S, cv. KKU2 with $40 \mathrm{~kg}$ $\mathrm{ha}^{-1}$ of $\mathrm{S}$ and KKU2 with $80 \mathrm{~kg} \mathrm{ha}^{-1}$ of $\mathrm{S}(10.37,10.24$ and 10.05 $\mathrm{g} \mathrm{pl}^{-1}$ respectively) (Fig. $1 \mathrm{~B}$ ).

Oil content did not show significant differences among sesame cultivar and levels of S (Table 9) suggesting that neither the cultivar or $\mathrm{S}$ had any influence on the seed oil content. Surprisingly, a highly significant influence was recorded for the interaction of cultivar and levels of S. A combination of KKU3 and $0 \mathrm{~kg} \mathrm{ha}^{-1}$ of $\mathrm{S}$ recorded the highest oil content at $56.61 \%$ while the lowest oil content was recorded in a combination of MK60 and $0 \mathrm{~kg} \mathrm{ha}^{-1}$ at $39.28 \%$ (Figure $1 \mathrm{C}$ ).

\section{Materials and methods}

The experiments were conducted over two seasons under pot conditions in Maha Sarakham University (Department of Agricultural Technology), Maha Sarakham province Thailand. The study was done between January to December year 2020, the first study was during dry season between January to April 2020 followed by wet season study between May - August 2020.

\section{Plant materials}

Three Thai cultivars were used for our study; cv. Maha Sarakham60 (MK60) (white seed color) was kindly donated by Kalasin University, cv. KKU2 (black seed color) and cv. KKU3 (brown seed color) were kindly donated by Khon Khan University.

\section{S application}

Four levels of $\mathrm{S}$ were used as treatments as per Raza et al., (2018a) with some minor modifications; The levels of $S$ for our current study were set as 0, 20, 40 and $80 \mathrm{~kg} \mathrm{ha}^{-1}$.

Experimental design and treatments

The experiment was arranged in $3 \times 4$ factorial in RCBD with three replications. Factor A was three cultivars of sesame namely MK60, KKU2 and KKU3. Factor B was the levels of S; 0 , 20,40 and $80 \mathrm{~kg} \mathrm{ha}^{-1}$. The soil texture used was classified as sandy with low fertility (Supp Table 1), with good drainage capacity. The dimensions of the pot were $20 \times 28 \mathrm{~cm}(\mathrm{DxH})$, each pot contained $8.0 \mathrm{~kg}$ of soil.

\section{Agronomic practice}

The sesame seeds were planted into the pot with basal fertilizer formula $15-15-15$ at rate $187.5 \mathrm{~kg} \mathrm{ha}^{-1}$. After $14-15$ days after planting, the seedlings were thinned to remain with 2 plants per pot, and one month after planting, fertilizer at the same rate and formula was applied. Irrigation was performed twice a week and weeds were removed manually by hands.

\section{Data collection}

Four plants from each experimental plot were selected for data collection. The plant growth parameters (height and number of branches $\mathrm{pl}^{-1}$,) were collected at 30,45, 60, 75 and 90 DAP with some variation on collections time. Number of capsules $\mathrm{pl}^{-1}$ was observed at 60, 75 and 90 DAP. The total dry weight, shoot dry weight, leaf dry weight and root dry weight $\left(\mathrm{g} \mathrm{pl}^{-1}\right)$ were collected at harvesting day then oven dried at 60 o $\mathrm{C}$ for $72 \mathrm{hr}$ (or until constant dry weight) then the mass was collected and results used for shoot root ratio (S/R ratio). Seed weight and thousand seed weight also were recorded after threshing. Oil content $(w / w)$ was determined by Soxhlet extraction method.

The SCMR was measured at 60, 75 and 90 DAP using SPAD-502 meter (Minolta SPAD-502 meter, Tokyo, Japan). The chlorophyll content in leaves was measured following Moran (1982) briefly, a small leaf disc was cut using $1 \mathrm{~cm}^{2}$ cork border, then placed in a vial containing $5 \mathrm{ml} \operatorname{DMF}(\mathrm{N}, \mathrm{N}$-dimethyl formamide) and incubated in $4{ }^{\circ} \mathrm{C}$ for $24 \mathrm{~h}$ in dark. The chlorophyll extract was measured at 647 and $664 \mathrm{~nm}$ by a spectrophotometer. The equations to calculate for total chlorophyll, chlorophyll a ( $\mathrm{Chl} \mathrm{a)} \mathrm{and} \mathrm{b} \mathrm{(Chl} \mathrm{b)} \mathrm{were} \mathrm{as} \mathrm{follows:}$

Total Chl $=$ Chla + Chlb
Chla $=12.64(A 664)-2.99(A 647)$
Chlb $=-5.6(A 664)+23.24(A 647)$

\section{Data analysis}

All data recorded was analyzed using Statistix 9.0. An ANOVA (analysis of variance) was exercised to verify the overall significance of data. The least significance difference (LSD) test was employed to compare the means at $5 \%$ probability level (Steel and Torrie, 1980). A combined analysis between seasons was also performed to determine the interaction between sesame variety and the $\mathrm{S}$ level.

\section{Conclusions}

From the recent study we can conclude that $\mathrm{S}$ levels had an effect on few traits whereas most of the traits were influenced by season. The interaction between cultivar and $S$ levels on both seasons was also found. $S$ levels did not have any effect on plant height, number of branches plant ${ }^{-1}, S_{C M R}$, thousand seed weight, leaf dry weight and $\mathrm{HI}$ both in dry and wet season except for number of branches at 90 DAP in wet season. Sesame responded to $S$ levels mostly in dry season as compared to the wet season, i.e. number of capsules plant ${ }^{-1}$ (60 and $90 \mathrm{DAP}$ ), seed weight, shoot dry weight, total dry weight and S/R ratio responded at $20 \mathrm{~kg} \mathrm{ha}^{-1}$ of S, while highest oil content was at $80 \mathrm{~kg} \mathrm{ha}^{-1}$ of S. A combined analysis between season found that all traits (plant height, number of branches, thousand seed weight, total dry weight and oil content) were not significantly different except number of capsules. However, our research was conducted on pot culture and we therefore recommend for field experiment to study the effects of $S$ and cultivar under natural conditions. 


\section{Acknowledgments}

This research project was financially supported by Mahasarakham University (2020). We would like to thank the Department of Agricultural Technology, Faculty of Technology Mahasarakham University, Khon Khan University and Kalasin University for kind donation of sesame seed.

\section{References}

Ahmad J, Ahmad F, Iqbal S, Shah SMA, Ali M, Abbas MW, Nawaz H, Mehmood Z, Ali B and Ali S (2018) Growth and oil yield of sesame as influenced by $S$ and nitrogen. J Agric Res. 3(7): 1-4.

Akinoso R, Abaoba SA and Olayanju TMA (2010) Effects of moisture content and heat treatment on peroxide value and oxidation stability of un-refined sesame oil. Afr J Food Agric Nutr Develop. 10(10): 4268-4285.

Cui C, Liu Y, Liu Y, Cui X, Sun Z andDu Z (2021) Genome-wide association study of seed coat color in sesame (Sesamum indicum L.). PLoS ONE 16(5): e0251526. https://doi.org/10.1371/ journal.pone.0251526.

Dossa K, Diouf D, Wang L, Wei X, Zhang Y, Niang M, Fonceka D, Yu J, Mmadi MA, Yehouessi LW, Liao B, Zhang $X$ and Cisse $N$ (2017) The Emerging oilseed crop sesamum indicum enters the "Omics" era. Front Plant Sci. 8:1154. doi: 10.3389/fpls.2017.01154.

Gomez KA and Gomez AA (1984) Statistical Procedures for Agricultural Research, 2nd Edition. pp.704.

Islam MS, Ali MT, Hasan MK, Wais AH and Hakim MA (2019) Response of sulphur and zinc on the growth and yield traits of sesame (Sesamum indicum L.) at old Himalayan piedmont plain soil. ISPEC J of Agric Sci. 3(1): 98-115.

Jiang $D$, Yue $H$, Wollenweber B, Ten $W, M u H$, Bo $Y$, Dai T, Jing Q, and Cao W (2009) Effect of post anthesis drought and waterlogging on accumulation of high molecular weight glutenin subunits and glutenin macropolymers content in wheat grain. J Agron Crop Sci. 195: 89-97.

Kalegore NK, Kirde GD, Bhusari SA, Kasle SV and Shelke RI (2018) Effect of different level of phosphorus and son growth and yield attributes of sesame. Int J Econ Plants. 5(4):163166.

Khan N, Khalil SK, Amanullah, Ali A, Ullah Z and Ali M (2016) Effect of nitrogen and sulfur on yield and yield components of sesame (Sesamum indicum L.) in calcareous soil. Pure Appl Biol. 5(3): 471-475.

Moran R (1982) Formulae for determination of chlorophyllous pigments extracted with N,N-Dimethylformamide. Plant Physiol. 69: 1376-1381.

Pal D, Phool C and Neetu (2020) Sesame seed in controlling human health and nutrition. Nuts and Seeds in Health and Disease Prevention (Second Edition). 183-210.

Parmar NN, Patel AP and Choudhary M (2018) Effect of sources and levels of $S$ on growth, yield and quality of summer sesame under South Gujarat Condition (Sesamum indicum L.). Int J Curr Microbiol Appl Sci. 7(2): 2600-2605.
Patel JR and Shelke VB (1995) Effect of farmyard manure, phosphorus and Son growth, yield and quality of Indian mustard. Indian J Agron 43: 713-717.

Paul SK, Khatun MM and Sarkar MAR (2019) Effect of S on the seed yield and oil content of sesame (Sesamum indicum L.). J Bangladesh Agril Univ. 17(1): 33-38.

Pathak N, Rai AK, Kumari R, Thapa A and Bhat KV (2014) Sesame crop: An under exploited oilseed holds tremendous potential for enhanced food value. Agric Sci. 2: 278-285.

Raja A, Hattab KO, Gurusamy L and Suganya S (2007) S levels on nutrient uptake and yield of sesame varieties and nutrient availability. Int J Soil Sci. 5: 278-285.

Raza MA, Ling YF, Abdul M, Allah W, Muhammad A, Anwaar $\mathrm{H}$, Muhammad HBK, Nasir I, Zeng JX, Yuan KC, Jun XC, Feng Y and Wenyu Yang (2008b) Sulphur application increases seed yield and oil content in sesame seeds under rainfed conditions. Field Crops Res. 218: 51-58.

Raza MA, Ling YF, Nasir I, Abdul M, Muhammad HBK, Sana ur R, Allah W, Muhammad A, Masum B, Feng $Y$ and Wenyu $Y$ (2008b) Effect of sulphur application on photosynthesis and biomass accumulation of sesame varieties under rainfed conditions. Agron. 8(149): 1-16.

Samant TK (2020) Effect of biofertilisers and sulphur on growth, yield, economics and post-harvest soil chemical properties in sesame (Sesamum Indicum L.). Chem Sci Rev Lett. 9 (34): 475-480.

Scherer HW (2001) S in crop production. Eur J Agron. 14(2): 81-111.

Shah MA, Manaf A, Hussain M, Farooq S and Hye MZU (2013) Sulphur fertilization improves the sesame productivity and economic returns under rainfed conditions. Int J Agric Biol. 15: 1301-1306.

Tahir M, Ibrahim MA, Tahir S, Ayub A, Tanveer A and Rehman $H$ (2014) Effect of sulfur levels on two sesame (Sesamum indicum L.) varieties under climatic conditions of Pakistan. Int J Plant and Soil Sci. 3(3): 281-288.

Uzun B, Arsain C and Furrat S (2008) Variation in fatty acid compositions, oil content and oil yield in a germplasm collection of sesame (Sesamum indicum L.). J Am Oil Chem Soc J Am Oil Chem Soc. 85: 1135-1142.

Walcal C, Basalirwa D, Okello-Anyanga W, Murongo MF, Namirembe C, Malingumu R (2021) Analysis of sesame seed production and export trends; challenges and strategies towards increasing production in Uganda. Uganda. Oil Crop Lip. 28: 4.

Wei X, Lui K, Zhang Y, Feng Q, Wang L, Zhoa Y, Li D, Zhoa Q, Zhu $X$ and Zhu X (2015) Genetic discovery for oil production and quality in sesame. Nat Commun. 6. 